MARINE MAMMAL SCIENCE, 2(3):214-222 (July 1986)

(C) 1986 by the Society for Marine Mammalogy

\title{
THE DISTRIBUTION OF BOWHEAD WHALES, BALAENA MYSTICETUS, IN THE CHUKCHI SEA
}

\author{
R. V. Muller \\ D. J. RugH \\ J. H. JoHNSON ${ }^{1}$ \\ National Marine Mammal Laboratory, \\ Northwest and Alaska Fisheries Center, \\ National Marine Fisheries Service, \\ National Oceanic and Atmospheric Administration, \\ 7600 Sand Point Way N.E., Bldg. 4, \\ Seattle, Washington 98115
}

\begin{abstract}
Under a U.S.-U.S.S.R. cooperative Marine Mammal Project, shipboard cruises were made in 1979,1980 and 1982, primarily to determine whether there is a substock of western Arctic bowhead whales (Balaena mysticetus) that summers in the western Chukchi Sea instead of migrating to the Beaufort Sea. More than 100 bowheads were sighted along the north Chukotka coast of Siberia in October 1979, and more than 200 bowheads were sighted there in September 1980. None were seen anywhere in the Chukchi Sea in late July and August 1982. We conclude that the September and October sightings were of animals returning early from the Beaufort Sea and that, other than occurrences peripheral to the main migration, there are no large concentrations in the Chukchi in the summer and there is apparently no western Chukchi substock.
\end{abstract}

Key words: bowhead whale, Balaena mysticetus, Chukchi Sea.

The western Arctic stock of bowhead whales regularly migrates from the Bering Sea to the Beaufort Sea. It apparently winters near the pack ice in the western Bering Sea from St. Lawrence Island south to St. Matthew Island, west to the U.S.S.R. coast and into the Gulf of Anadyr (Braham et al. 1980b, Bogoslovskaya et al. 1982, Brueggeman 1982). Braham et al. (1980a) summarized the spring migration as occurring from April through June in a generally northeastward movement from the western Bering Sea through the eastern Chukchi Sea and into the Beaufort Sea. The Canadian Beaufort Sea apparently

${ }^{1}$ Deceased. 
serves as the primary summer feeding ground, and from June through September bowhead whales frequent the area south and southwest of Banks Island to the coast between Amundsen Gulf and Herschel Island. Braham (1984) reviewed previous studies on the autumn migration westward through the U.S. Beaufort Sea. He described it as beginning in August and continuing into November, with sightings typically occurring in September and October near the 20-100 m depth contour between Demarcation Bay and Point Barrow. From Point Barrow the animals apparently move west and southwest across the Chukchi Sea, then south and east along the Chukotka coast and through the Bering Strait, arriving at their winter grounds in the Bering Sea in November and December (Braham et al. 1984, Moore et al. 1985).

Most sightings of bowheads in recent times support these conclusions. Even though records from commercial whaling in the 1800s indicate that the species was abundant during the summer in the Bering and Chukchi seas (Townsend 1935), Dahlheim et al. (1980) found none there when they searched 13 June15 July 1978. Although 1,238 cetaceans were recorded and nearly ideal observation conditions prevailed in areas where summering bowheads might be expected, none were found. The same authors documented other ship surveys and collected information from knowledgeable Eskimos, all of which corroborated the conclusion that few if any bowheads occur in these seas during the summer. Marine mammal sightings have been gathered opportunistically since 1958 from ships in Alaskan waters through the National Marine Mammal Laboratory's Platforms of Opportunity Program. Among 11,200 marine mammal sightings occurring north of $55^{\circ} \mathrm{N}$ latitude, only three bowhead whales (each listed as tentative) were recorded for the months of June, July and August in the Bering and Chukchi seas.

Conversely, it has been argued that some bowhead whales migrate north in the spring into the western Chukchi Sea, either splitting off from the migration to the Beaufort Sea or perhaps occurring as a late group of migrants (Braham et al. 1980a, Bogoslovskaya et al. 1982). The implication is that those whales not migrating to the Beaufort Sea would not be counted in spring censuses conducted at Point Barrow and, therefore, an upward correction would be needed for any population estimate. Some recent sightings seem to follow such a pattern; Sergeant and Hoek (1974), for example, reported up to 100 bowheads on 11 July 1974 in the Bering Strait $\left(67^{\circ} 11^{\prime} \mathrm{N}, 168^{\circ} 07^{\prime} \mathrm{W}\right)$. Also Ray and Wartzok (1980) reported 64 bowheads in the central to eastern Chukchi Sea (particularly between Wainwright and Icy Cape) in August 1975, a heavy ice year. Those authors, however, emphasized environmental conditions as being more critical to the distribution of bowheads than strictly geographical factors. Consequently, the joint U.S.-U.S.S.R. Marine Mammal Project, within the Environmental Protection Agreement, attached high priority to documenting the summer-fall distribution of bowhead whales in the western Chukchi Sea and, to that end, carried out three cooperative research cruises in the Chukchi Sea in the years 1979 (5-23 October), 1980 (16 September-1 October) and 1982 (25 July-24 August). Figures 1-3 show the cruise tracks and cetaceans sighted for the three surveys. The temporal and geographic coverage appears 
to be reasonably complete for the period from late July to late October, with the exception of late August to mid-September.

\section{METHODS}

Soviet whaling ships, K/S Avangard, K/S Razyatschyi and K/S Entuziast, were provided by the U.S.S.R. in 1979, 1980 and 1982, respectively. Each ship was approximately $64 \mathrm{~m}$ in length, with a $20-33 \mathrm{~km} / \mathrm{h}$ cruising speed and rapid turning capabilities; however, they were not icebreakers and their penetration into the polar pack ice was limited.

On each cruise, two to six observers stood on a flying bridge approximately $11 \mathrm{~m}$ above water level, recording sightings during virtually all daylight transiting hours except during inclement weather. During the night the ship usually maintained a stationary location. Tracklines were chosen principally in ice front areas but were not based on statistically prescribed patterns. For most sightings. the ship approached the whale(s) to confirm species and numbers. Location was cstablishcd by mcans of a shipboard radio dircction findcr. In 1979 and 1980 biopsy samples of skin and blubber were collected from bowheads by approaching to within $25 \mathrm{~m}$ of a whale and, with a crossbow, launching an arrow with a small metal coring tube attached. Unfortunately, these biopsies were not useable.

\section{SuRvey Results}

\section{Survey}

Johnson et al. (1981) summarized the results of the 5-21 October 1979 cruise of the K/S Avangard, during which more than 100 bowheads were observed along the Chukotka coast (Fig. 1). No bowhead whales were sighted during the Bering Sea portion of the cruise. In the western Chukchi Sea, bowhead whales were found primarily along the north Chukotka coast, with a few animals occurring in open water between the coast and Herald Island, and in the immediate vicinity of Herald Island. Conversely, the distribution of gray whales was offshore in the south-central Chukchi Sea, with a few animals near the coast just north of the Bering Strait (Miller et al. 1985).

Other than bowhead and gray whales, the only marine mammals sighted were walrus (Odobenus rosmarus) encountered intermittently throughout the cruise in numbers ranging from a single to several thousand animals.

\section{Survey}

On the 1980 cruise of the K./S Razyalschyi (Marquette et al. 1982), bowhead whales were sighted along the Chukotka coast from Cape Serdtse-Kamen to Cape Schmidt with the largest concentration occurring, as in 1979, in the area near Cape Vankarem (Fig. 2). Gray whales were sighted from Cape Vankarem westward in Long Strait and in the East Siberian Sea, the farthest west yet recorded at $174^{\circ} 08^{\prime} \mathrm{E}$ longitude (Miller et al. 1985).

Other cetacean species sighted, each in small numbers along the north Chukotka coast, included humpback whales (Megaptera novaeangliae), killer whales 


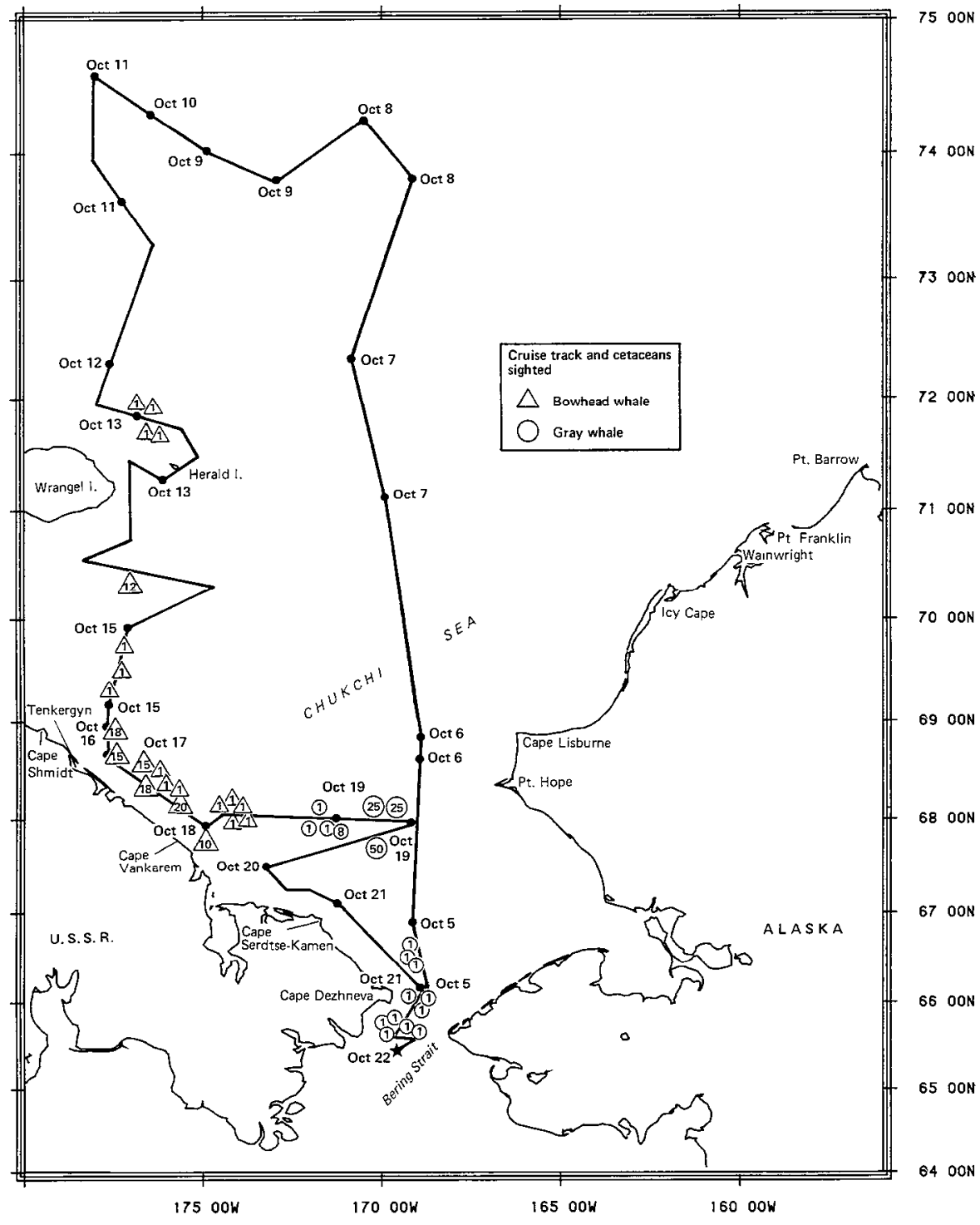

Figure 1. Cruise track and cetaceans sighted on K/S Avangard, 5-23 October 1979.

(Orcinus orca) and minke whales (Balaenoptera acutorostrata) (Fig. 2). Fewer than 100 walruses were seen, plus 30 or more unidentified seals and three polar bears.

\section{Survey}

In 1982, the third in the series of joing U.S.-U.S.S.R. cruises was conducted from 25 July to 24 August. The cruise track of the $\mathrm{K} / \mathrm{S}$ Entuziast during this 


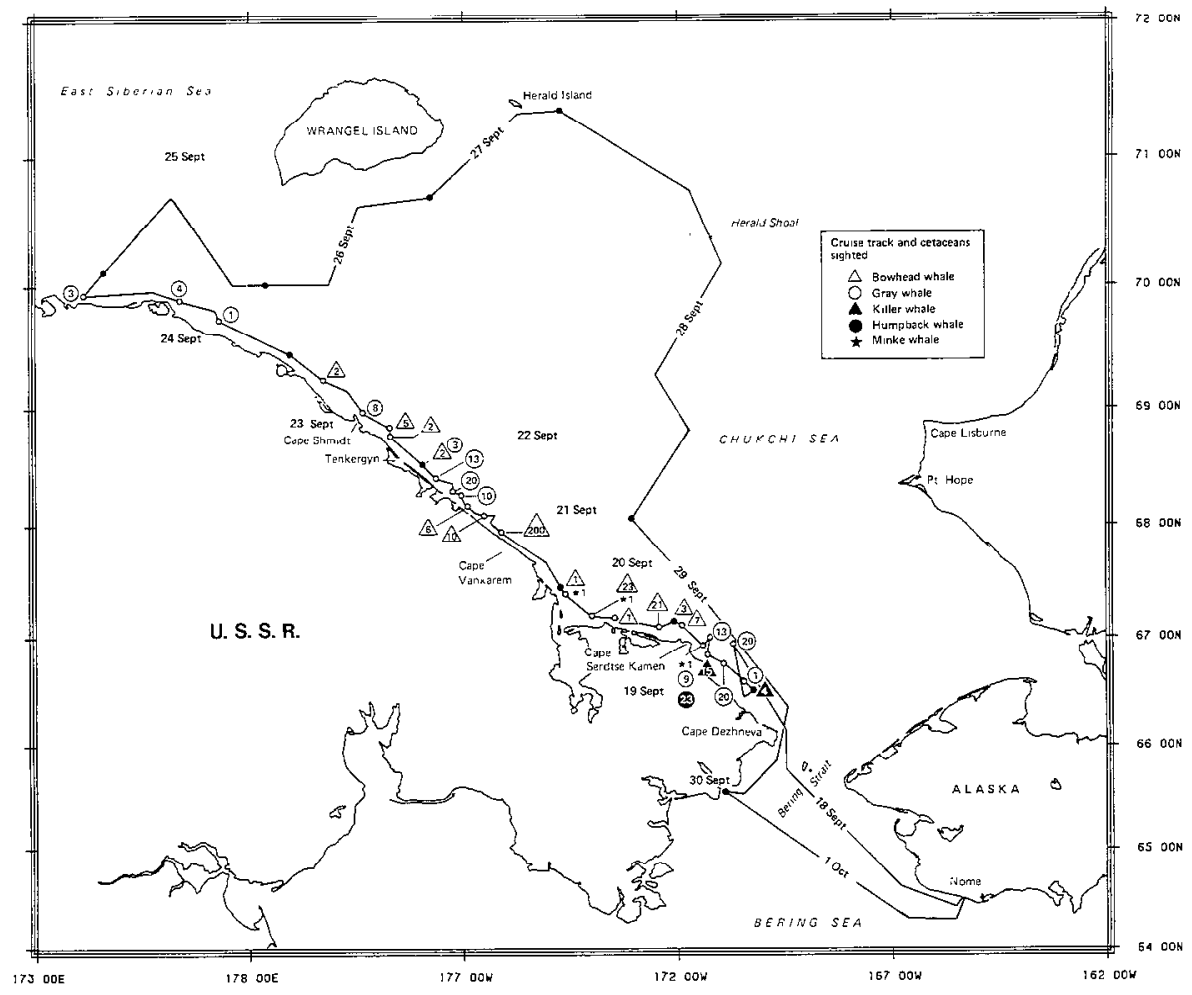

Figure 2. Cruise track and cetaceans sighted on K/S Razyatschyi, 16 September-1 October 1980.

time period (Fig. 3) encompasscd two full circuits of the Chulkchi Sea, generally following the perimeter of open water, with a concluding series of transects southward through the central Chukchi Sea. The cruise was continued without American scientists from 25 August to 7 October (Doroshenko and Kolesnikov 1983).

No bowhead whales were seen throughout the joint participation phase of the cruise, but large concentrations of gray whales (totaling 1,182 animals) were seen along the Chukotka coast from approximately north of Cape Dezhneva to Cape Vankarem and in the northeastern part of the Chukchi Sea from Wainwright to Point Franklin, south of the pack ice (Fig. 3). Small groups of gray whales were also sighted along the Alaskan coast south of Wainwright, near Herald Shoals, and well offshore northeast of Cape Shmidt (Fig. 3). A total of 54 gray whales were tagged with Discovery marks by Soviet scientists during this cruise. Nine minke whales were seen, mostly in the southern Chukchi Sea. Also, more than 10,000 walrus were recorded, many of which were identified as to age and sex (Fay and Kelly 1982). In addition, about 250 ringed seals (Phoca hispida), 100 bearded seals (Erignatbus barbatus) and three ribbon seals (Pboca fasciata) were counted. 


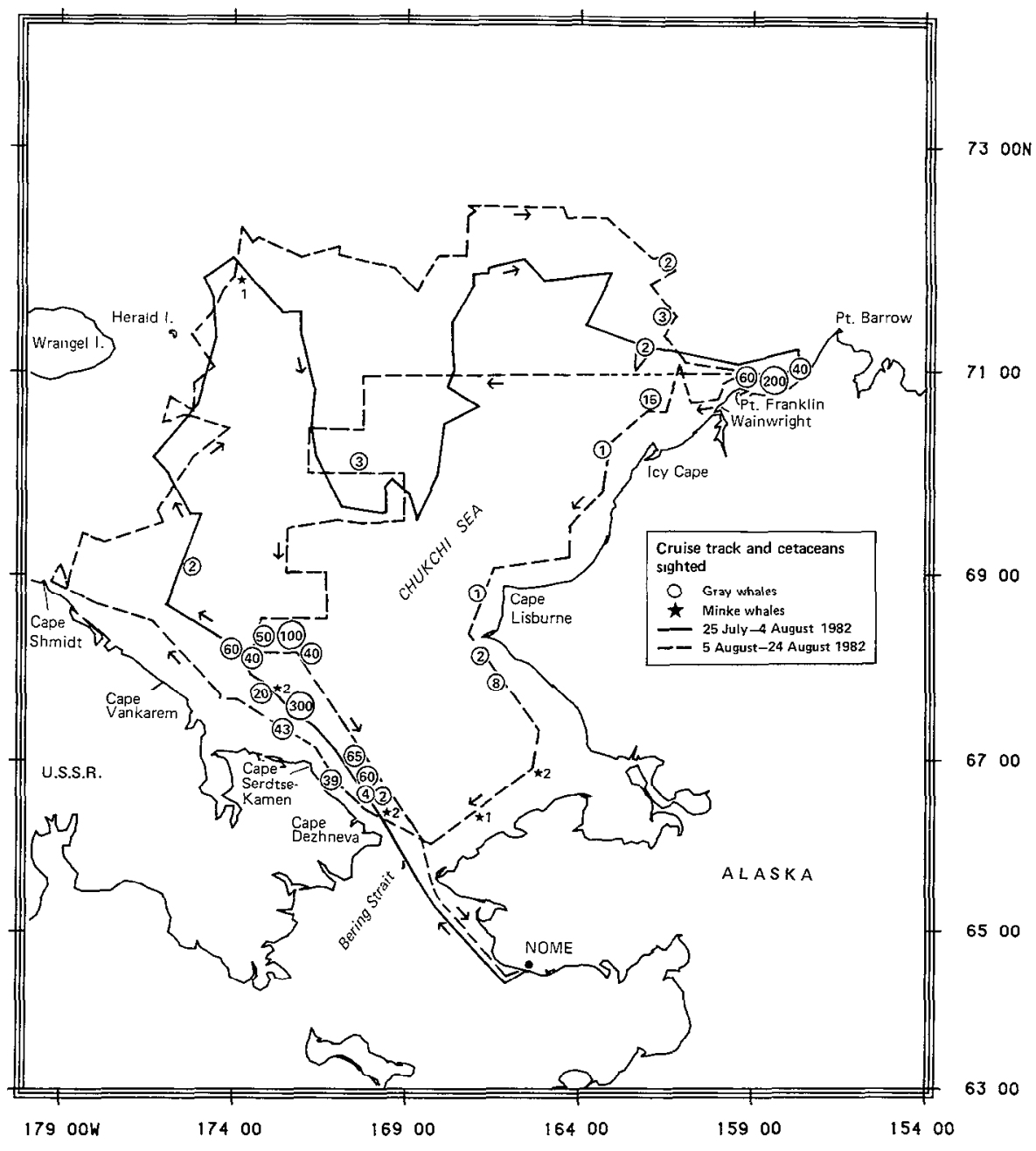

Figure 3. Cruise rack and cetacearss sighted on K/S Entuziast, 25 July-24 August 1982.

Doroshenko and Kolesnikov (1983) reported on the continuation of the cruise from 25 August to 7 October after the U.S. observers departed in Nome, Alaska. The cruise track proceeded from Nome west to the Chukotka Peninsula, through the Bering Strait and along the north coast of Chukotka as far as $179^{\circ} 19^{\prime} \mathrm{W}$ longitude in early September. During this period, two groups of 13 and 18 bowheads were observed near Kolyuchin Bay (no date given, but presumably on the return segment of the track, a few days after reaching Cape Shmidt on 8 September). Gray whales were observed in small (nine animals) to large (300 animals) concentrations from Cape Shmidt to Inchoun near Bering Strait. 


\section{Discussion}

Comparing the 1979 and 1980 cruises, some notable differences in the distribution of whales arc apparent. In 1980 bowheads were seen nearly 200 $\mathrm{km}$ farther southeast than the southernmost sighting in 1979, even though the 1980 cruise was made a full month earlier in the year. In 1979, north of the Bering Strait, gray whales were not seen along the Chukotka coast; instead they were observed well offshore and widely separated from bowhead whales. By contrast, in 1980 bowhead and gray whales alternated along the coast (with no intermixing) and no gray whales were observed far offshore. In both years the greatest concentration of bowhead whales was observed in the general area of Cape Vankarem. We infer from these data that the habitat (i.e., food supply or other factors) in the Cape Vankarem area may be particularly suitable for bowheads.

The absence of bowhead sightings throughout the surveyed area of the Chukchi Sea in the summer of 1982 and the later sighting of two groups in September of that year support the hypothesis that the bowheads observed along the north Chukotka coast from mid- to late-fall in 1979 and 1980 were not summer residents of that area but probably were animals of the principal stock returning from the Beaufort Sea.

Other sightings in the Chukchi Sea also typically occurred in the fall. Kuz'min and Berzin (1975) recorded two groups (three individuals in the southern Chukchi Sea and two in the Bering Strait) on 13 October 1974, and Bogoslovskaya et al. (1982) indicated that bowheads are commonly seen along the north Chukotka coast from late summer to early November. Furthermore, bowhead whales were absent along the Chukotka coast west of $179^{\circ} \mathrm{E}$ longitude in 1980 , even though gray whales were present as far west as $174^{\circ} \mathrm{E}$ longitude. Considering that our 1980 observations were made in late September, apparently well before freeze-up, they strongly suggest the absence of a separate stock of bowheads occupying the western Chukchi or East Siberian Seas.

Alternatively, Bogoslovskaya et al. (1982) reported that bowhead whales are "regularly" observed passing Inchoun Village ( $170^{\circ} \mathrm{W}$ longitude) and "very many whales" were observed by the villagers in May 1980 , moving northwest in leads about $2-3 \mathrm{~km}$ from shore. These reports, along with earlier records of occasional sightings in summer as far west as the East Siberian Sea (sightings near Ayon Island in August 1976 and a dead bowhead calf the same summer on an ice block in Malyy Chaunskiy Strait are the westernmost records), suggest a separate northwest migration. It should be pointed out, however, that in the spring of 1980 a heavy blockage of pack ice in the Bering Strait delayed the spring migration of bowheads to the northeast by about one month (Johnson et al. 1981). The ice blockage led to large numbers of whales "milling about" south of the blockage, and whales moving into areas where they are rarely reported, such as near Shaktoolik, well into Norton Sound. Those same conditions may have also caused a number of bowheads to move westward and pass through leads along the Soviet coast, but probably no further west than $175^{\circ} \mathrm{W}$ longitude. This information, coupled with the reports of Ray and Wartzok (1980) and Sergeant and Hoek (1974) support the view that bowhead migra- 
tion timing and route(s) are probably strongly influenced by environmental conditions, particularly ice coverage. Considering the limitations of viewing area from shipboard transects and the variety of whale distributions that may occur betwcen seasons with different ice conditions, further research is needed to better define routes, timing and distribution of bowheads during their fall migration. However, with the available information, based upon evidence acquired during the three joint U.S.-U.S.S.R. research cruises and available literature, we conclude that the bowhead whales observed in the western Chukchi Sea in the fall season were most likely returning migrants from the Beaufort Sea.

\section{ACKNOWLEDGMENTS}

Francis H. Fay, G. Carleton Ray, Mitchell Taylor, Kenneth Coyle, Robert Nelson and Brendan Kelly shared in the collection of pinniped observations and trophic data. Our Soviet colleagues, N. Doroshenko (1979-1980) and V. Koleznikov (1982), served ably as cruise chief scientists. Special thanks to Capt. G. Timchenko (K/S Avangard) and Capt. V. Chevchenko (K/S Razyatschyi and K/S Entuziast) and their crews for the highly professional, courteous and friendly treatment we received aboard their ships. Also thanks to the Nome office staff of the Alaska Department of Fish and Game and the Alaska Communications System, the North Slope Borough and to many persons in Nome, Gambell and Wainwright, Alaska, for their kind support. G. C. Bouchet provided a search of the National Marine Mammal Laboratory's Platforms of Opportunity Program data base.

\section{LiteratURe Cited}

Bogoslovskaya, L. S., L. M. Votrogov and I. I. KRUPNik. 1982. The bowhead whale off Chukotka: Migrations and aboriginal whaling. Report to the International Whaling Commission 32:391-399.

Braham, H. W. 1984. The bowhead whale, Balaena mysticetus. Marine Fisheries Review 46(4):45-53.

Braham, H. W., M. A. Fraker and B. D. Krogman. 1980a. Spring migration of the western Arctic population of bowhead whales. Marine Fisheries Review 42(910):36-46.

Braham, H. W., B. Krogman, J. Johnson, W. Marquette, D. Rugh, M. Nerini, R. Sonntag, T. Bray, J. Brueggeman, M. Dahlmeim, S. Savage and C. Goebel. 19806. Population studies of the bowhead whale (Balaena mysticetus): Results of the 1979 spring research season. Report to the International Whaling Commission 30:391-404.

Braham, H. W., B. D. Krogman and G. M. Carroll. 1984. Bowhead and white whale migration, distribution, and abundance in the Bering, Chukchi, and Beaufort Seas, 1975-1978. U.S. Department of Commerce, NOAA Technical Report. NMFS SSRF-778. 39 pp.

BRUEGGEMAN, J. J. 1982. Early spring distribution of bowhead whales in the Bering Sea. Journal of Wildlife Management 46(4):1036-1044.

Dahlheim, M., T. BRAY ANd H. Braham. 1980. Vessel survey for bowhead whales in the Bering and Chukchi Seas, June-July 1978. Marine Fisheries Review 42(9-10): $51-57$.

Doroshenko, N. V., and V. N. Kolesnikov. 1983. Results of investigations of whales in the Bering and Chukchi Seas in 1982 by Soviet R/V ENTUZIAST. Unpublished report to the International Whaling Commission. SC/35/PS20. Pages 1-8, 2 figs. International Whaling Commission, The Red House, Station Road, Histon, Cambridge CB4 4NP, U.K. 
FAY, F. H., AND B. P. KeLIY. 1982. Herd composition and response to disturbance of walruses in the Chukchi Sea. Cruise Report, K/S ENTUZIAST, 25 July-23 August 1982. NOAA-OCSEAP/R.U. \#611.13 pp. Alaska Office, Outer Continental Shelf Environmental Assessment Program (OCSEAP), P.O. 1808, Juneau, Alaska 99802.

Johnson, J. H., H. W. Braham, B. D. Krogman, W. M. Marquette, R. M. Sonntag AND D. J. Rugh. 1981. Research conducted on bowhead whales, June 1979 to June 1980. Report to the International Whaling Commission 31:461-475.

Kuz'min, A. A., ANd A. A. Berzin. 1975. Raspredelenie $i$ sovremennoe sostoianie chislennosti gladkikh i serykh kotov $\mathrm{v}$ dal'nevostochnykh moriakh (Distribution and current numbers of right and gray whales in the far-east seas). Pages 121-122 in Papers of the All-Union Conference, Oct. 1975, Vladivostok-Biologicheskie resursy morei dal'nego vostoka (Biological resources of the far-east seas). Ichthyological Commission of the Ministry of Fisheries of the USSR, Pacific Research Institute Fisheries and Oceanography. [TINRO.] In Russian. (Translation available through National Marine Fisheries Service, Office of International Fisheries, I anguage Service Branch, Washington, D.C., 2 pp.)

Marquette, W. M., H. W. Braham, M. K. Nerini and R. V. Miller. 1982. Bowhead whale studies, autumn 1980-spring 1981: harvest, biology, and distribution. Report to the International Whaling Commission 32:357-370.

Miller, R. V., J. H. Johnson AND N. V. Doroshenko. 1985. Gray whales (Eschrichtius robustus) in the western Chukchi and East Siberian Seas. Arctic 38(1):58-60.

Moore, S. E., J. T. Clarke AND D. K. Ljungblad. 1985. A comparison of gray whale (Eschrictius robustus) and bowhead whale (Balaena mysticetus) distribution, abundance, habitat preference and behavior in the northeastern Chukchi Sea, 19821984. Report submitted to the International Whaling Commission, June 1985 (SC/37/PS2).

RAY, G. C., AND D. WARTZOK. 1980. Remote sensing of marine mammals of Beringea; Results of BESMEX: The Bering Sea Marine Mammal Experiment. Final Report of Contract No. NAS2-9300 for National Aeronautics and Space Administration, 77 pp. John Hopkins University, Department of Pathobiology, 615 North Wolfe Street, Baltimore, Maryland 21205.

Sergeant, D. E., AND H. Hoek. 1974. Biology of bowhead Balaena mysticetus and white whale Delphinapterus leucas in the Beaufort Sea. Interim Report of Beaufort Sea Project Study A4, Victoria, British Columbia, Canada, 15 pp.

Townsend, C. H. 1935. The distribution of certain whales as shown by logbook records of American whaleships. Zoologica (N.Y.) 19(1):3-50.

Received: January 6, 1986

Accepted: April 17, 1986 